\title{
The Prediction of Success of TEOG in the History of Revolution and Kemalism Course at the Stage of Transition from TEOG to LGS
}

\author{
İbrahim Sari \\ Faculty of Education, Dumlupiar University, Kutahya, Turkey
}

Copyright $\bigcirc 2018$ by authors, all rights reserved. Authors agree that this article remains permanently open access under the terms of the Creative Commons Attribution License 4.0 International License

\begin{abstract}
This research was conducted in order to predict the success of TEOG in the History of Revolution and Kemalism course. This research conducted with quantitative research method was carried out on the data of 477 students attending in 5 different secondary schools and 18 classrooms in these state schools affiliated to Kütahya Provincial National Education Directorate. The data of the study consisted of the fall and spring semester written exam success scores in 8th grade Revolution History and Kemalism Course and the success scores of TEOG I and II in the same course in the 2016-2017 academic year. In the analysis of the data, firstly, the correlational analysis was applied and then regression analysis was performed. As a result of the research, it was determined that the first written exam of the Revolutionary History and Kemalism course announced about $59 \%$ of the variance in the TEOG I success scores. Another conclusion reached was that the first written exam in the spring semester of the Turkish Revolution History and Kemalism course accounted for approximately $65 \%$ of the variance in the TEOG II success scores. In addition, TEOG I and Revolution History and Kemalism course, the first written exam in the spring semester variables were found to explain approximately $77 \%$ of the variance in TEOG II success scores. Based on the results of the research, discussions and suggestions were made.
\end{abstract}

Keywords TEOG, Academic Achievement Prediction, History of Revolution and Kemalism Course

\section{Introduction}

Education is a social institution and all social institutions realize themselves through specific social units. "The Education System" is called the social unit formed by education which is a social institution [7]. The education systems integrate with the communities they belong to and provide the students with the ability to control and adapt to the environment. Nowadays, the increase in the needs of the qualified manpower of the societies requires the changing of the selection criteria of the students who will take place in the education systems. This requirement has led to changes in educational paradigms, where the student is brought to the centre, individual differences are taken into consideration, and that each student is responsible for their own learning [20].

Like all other systems, the Education System consists of elements with input, output, environment and feedback. These elements include a number of subsystems. The Turkish Education System consists of stages that have been influenced by each other and affected each other from pre-school to higher education. The evaluation of the students studying at these stages is also part of the system. In many countries in the world, the exams that regulate the transition between levels in educational systems are applied in different ways $[17,10,16]$.

One of the most hotly debated issues in terms of the education system in Turkey regarding the entrance to secondary education, a lot of discussions were made and different applications were performed. These applications have been the central examination systems such as LGS (Entrance Examination for High Schools), OKS (Selection and Placement Examination of Secondary Education Institutions), SBS (Placement Examination for High Schools), TEOGS (Basic Education to Secondary Education Exam) and finally again LGS (Entrance Examination for High Schools). Although their names and periods are different from each other, the basis for entrance to secondary education is reduced to evaluation according to several exam results. Applications are generally aimed at increasing the quality of education or increasing or decreasing the number of exams rather than creating an effective learning process by eliminating inequalities 
between regions and schools [2]. Student achievements, teachers 'opinions, students' interests and abilities have been ignored and an effective guidance and orientation system has not been established.

According to the system introduced in the 2013-2014 academic year (TEOG), 30\% of teacher evaluations and one of the exams of Mathematics, Turkish, Science and Technology, the History of Revolution and Kemalism, English, Religious Culture and Moral Knowledge courses studied at school was taken into consideration by taking $70 \%$ of the average of the exams to be held centrally and student admission to the secondary education institutions could be done $[2,17,11,19]$. From this point of view, it is seen that this entrance system consists of result based exams and does not coincide with the process-based evaluation process applied in the constructivist approach.

In the last applied LGS, 8th grade students of public and private secondary schools, imam hatip secondary schools and temporary education centers (GEM) were aimed to be placed to science high schools, social sciences high schools, educational institutions implementing the project and Anatolian technical programs of vocational and technical Anatolian high schools (MOE, 2018).

As mentioned above, the historical changes from secondary school to the high school entrance exams in Turkey have brought many innovations and discussion of the agenda along with it.. This has led researchers to conduct research on many aspects of the content, validity and reliability of each new exam. It can be said that some of these studies are studies for predicting the students' TEOG successes.

A lot of research has been done in the related literature about variables affecting TEOG performance. In the study which was conducted by Önder [13], it is observed that the educational resources of schools are significant predictors of TEOG scores $\left(\mathrm{R}=.634 \mathrm{R}^{2}=.402\right)$. In the study conducted by Yavuz, Odabaş and Özdemir [18], it was found that TEOG mathematics achievement scores were significantly different between the students and between schools and the reason for this difference was that $91 \%$ of the students were originated from the students and only $9 \%$ were from the schools. As a result of the research conducted by Erol [5], it was found that $64.28 \%$ of the social studies teachers participating in the study found the TEOG examination system appropriate. It was concluded that the teachers who participated in the study both agreed about the History of Revolution and the lack of weekly hours of Kemalism course.

In the study of Aslan (2017), it is seen that the housing income, the annual education expenditure for the child and the education level of the parents predicted $30 \%$ of the TEOG scores $\left(\mathrm{R}^{2}=.301\right)$. In the study conducted by Kesici and Asilioglu [9], the anxiety, attitude, motivation and pre-test stress level of the students indicate a significant relationship with TEOG mathematics achievement $\left(\mathrm{R}=.495 ; \mathrm{R}^{2}=.245, \mathrm{p}<.05\right)$. It was found that these four variables explained $24.5 \%$ of the change in mathematics achievement together. In Dulkadir's [4] study, it was concluded that the students' mathematics anxiety levels were significantly correlated with mathematical scorecard grade $(\mathrm{r}(373)=-.350, \mathrm{p}<.001)$, general weighted grade point average $(\mathrm{r}(373)=-.237, \mathrm{p}<.001)$, TEOG math test raw score $(\mathrm{r}(373)=-.311, \mathrm{p}<.001)$, TEOG total raw score $(\mathrm{r}(373)=-.194, \mathrm{p}<.001)$, and the students' mathematics anxiety levels were significantly differentiated according to the gender and father education status variables. In Özdemir, Yakar and Yavuz's study [14], it was found that the lowest average of the report card components was the one obtained from the TEOG common exam. In addition, it was observed that the exam scores found on the report card components were close to each other. This situation was reflected in the results of the regression analysis in the form of strong examinations of the written exam scores.

As a result of the research conducted by Celikel and Karakus (2017), according to the teachers who gave the mathematics lesson, the mathematics lesson of the eighth-grade students was found to be in line with their success in the TEOG exam and their academic achievement. In the research of Özkan and Karatas [15], it was determined that the answers of the students about central examination system called TEOG which was first time started to be implemented in 2013 were consistent in terms of content and applications (scoring system, place of exam, exam time, exam type, exam method, result notification, question type, number of questions, scope of school courses), but as for level of feeling happy and comfortable during the central examinations were low. In the study of Akman [1], it was concluded that the views of the students about the TEOG examinations were generally positive but negative opinions also appeared.

In the study conducted by Yüksel, Sevim and Çelimli [21], it was revealed that the test anxiety and selective attention skills of the adolescents who took the TEOG examination formed $47 \%$ of the test performance $(\mathrm{R}=.69$; $\left.\mathrm{R}^{2}=.47 ; \mathrm{p}<.001\right)$. As a result of the research conducted by Okutan and Daşdemir [12], it was found that the variables of the educational status of the parents (in favour of parents having university degree), the number of siblings (in favour of students with a brother or a sister), type of school (in favour of private schools), and income level (in favour of the families having higher income level), having a study room (in favour of having a study room) had a significant effect on the success of the TEOG exam $(p=.000)$, the variables such as gender and rent status of the house were not affected by TEOG science success ( $\mathrm{p}>.05$ ).

It seems that studies about predicting the success of OKS, SBS, and TEOG which are organized for students to enter high schools mostly focus on the variables such as exam anxiety, income, and gender affecting the success $[13,5$, Aslan, 2017; 14]. Moreover, it can be said that the number of researches for predicting mathematics success in the TEOG exam on the basis of the course is relatively higher 
than the other subjects $[18,9,4,3]$. This study is highly important both in terms of determining the relationship between the success of TEOG exam and the written exam and the exams held by teachers related to the History of Revolution and Kemalism and determining how much the written exam results explain the variance in TEOG success. Furthermore, the fact that this study was carried out on the latest TEOG exam data will contribute to the discussions on the newly implemented LGS exam. In this context, the aim of the research is to predict the TEOG success of the 8th-grade students in the Secondary School on the History of Revolution and Kemalism. In accordance with this purpose, the following sub-problems were sought.

1. Is there a statistically significant relationship between the successes of the first written exam scores in the fall semester of students in the History of Revolution and Kemalism and TEOG I success?

2. Is the success of the first written exam scores in the fall semester of students in the History of Revolution and Kemalism significant predictors of TEOG I?

3. Is there a statistically significant relationship between the History of Revolution and Kemalism the first written success scores of the fall and spring semesters and the TEOG I and TEOG II success scores?

4. Are the students' first written exam results of the History of Revolution and Kemalism course a significant predictor of the success of TEOG II?

5. Is the first written exam success scores of the History of Revolution and Kemalism course and TEOG I success scores in the spring semester statistically a significant predictor of the success of the TEOG II?

\section{Materials and Methods}

\subsection{Research Model}

In this study, the research was carried out by descriptive screening method due to aiming to predict the success of TEOG in the course of the History of Revolution and Kemalism during the period of transition from TEOG to LGS. The screening model is a type of research that aims to describe a situation that exists in the past or the present state as it exists. In such researches, it is tried to define the characteristics of the participants' opinions such as interest, skill, ability, attitude as in their own conditions [6, 8].

\subsection{Study Group}

It consists of 477 students attending in 5 different secondary schools and 18 classrooms in these state schools affiliated to Kütahya Provincial National Education Directorate. The descriptive data for sampling are presented in Table 1.

Table 1. Demographic Characteristics of the Participants of the Research

\begin{tabular}{|c|c|c|c|c|}
\hline & \multicolumn{2}{|c|}{$\begin{array}{c}\text { Demographic } \\
\text { Features }\end{array}$} & Frequency & $\begin{array}{c}\text { Percentag } \\
\mathrm{e}\end{array}$ \\
\hline \multirow{3}{*}{$\begin{array}{c}\text { Yunus Emre } \\
\text { Secondary } \\
\text { School }\end{array}$} & \multirow{3}{*}{ Gender } & Female & 31 & 51.7 \\
\hline & & Male & 29 & 48.3 \\
\hline & & Total & 60 & 12.6 \\
\hline \multirow{3}{*}{$\begin{array}{c}\text { Çamlica } \\
\text { Secondary } \\
\text { School }\end{array}$} & \multirow{3}{*}{ Gender } & Female & 10 & 47.6 \\
\hline & & Male & 11 & 52.4 \\
\hline & & Total & 21 & 4.4 \\
\hline \multirow{3}{*}{$\begin{array}{c}\text { Linyit } \\
\text { Secondary } \\
\text { School }\end{array}$} & \multirow{3}{*}{ Gender } & Female & 84 & 45.2 \\
\hline & & Male & 102 & 54.8 \\
\hline & & Total & 186 & 39 \\
\hline \multirow{3}{*}{$\begin{array}{c}\text { Atakent } \\
\text { Secondary } \\
\text { School }\end{array}$} & \multirow{3}{*}{ Gender } & Female & 64 & 49.2 \\
\hline & & Male & 66 & 50.8 \\
\hline & & Total & 130 & 27.3 \\
\hline \multirow{3}{*}{$\begin{array}{c}\text { Atatürk } \\
\text { Secondary } \\
\text { School }\end{array}$} & \multirow{3}{*}{ Gender } & Female & 43 & 53.8 \\
\hline & & Male & 37 & 46.3 \\
\hline & & Total & 80 & 16.8 \\
\hline Total & & & 477 & 100 \\
\hline
\end{tabular}

When Table 1 is examined, it is seen that the number of students in schools had at least 21 and maximum 186 students. According to the gender variable, it has been seen that $48.63 \%$ (232) of the 477 students in total were female, and approximately $52 \%$ (245) of them were male.

\subsection{Data Collection Tool}

In line with the purpose of the study, the first written exam results of 2016-2017 academic year fall semester of the History of Revolution and Kemalism courses and the same period TEOG I the History of Revolution and Kemalism exam results were taken into consideration. In addition, the first written exam results of 2016-2017 academic year spring semester of the History of Revolution and Kemalism courses and the same period TEOG II the History of Revolution and Kemalism exam results were used in the study.

\subsection{Data Analysis}

At the beginning of the 2017-2018 academic year, Pearson correlation coefficient and regression analyses were applied to the collected data. Statistical analysis was performed in R studio program.

\section{Results}

The descriptive statistics of the students about the TEOG related to the History of Revolution and Kemalism course are given in Table 2 . 
Table 2. Descriptive Data on TEOG1 and TEOG2 exams of the students.

\begin{tabular}{|c|c|c|c|c|c|c|}
\hline School & Exams & Sampling & Min. & Max. & Means & Standard Deviation \\
\hline \multirow{2}{*}{$\begin{array}{c}\text { Yunus Emre } \\
\text { Secondary School }\end{array}$} & TEOG 1 & \multirow{2}{*}{60} & 10 & 95 & 52.3 & 21.75 \\
\hline & TEOG 2 & & 10 & 100 & 60.3 & 25.13 \\
\hline \multirow{2}{*}{$\begin{array}{c}\text { Çamlıca Secondary } \\
\text { School }\end{array}$} & TEOG 1 & \multirow{2}{*}{21} & 25 & 90 & 54.8 & 22.66 \\
\hline & TEOG 2 & & 20 & 100 & 67.6 & 23.11 \\
\hline \multirow{2}{*}{$\begin{array}{c}\text { Linyit Secondary } \\
\text { School }\end{array}$} & TEOG 1 & \multirow{2}{*}{186} & 20 & 100 & 77.6 & 20.94 \\
\hline & TEOG 2 & & 15 & 100 & 86.7 & 17.48 \\
\hline \multirow{2}{*}{$\begin{array}{c}\text { Atakent Secondary } \\
\text { School }\end{array}$} & TEOG 1 & \multirow{2}{*}{130} & 10 & 100 & 65.3 & 24.87 \\
\hline & TEOG 2 & & 10 & 100 & 77.7 & 21.42 \\
\hline \multirow{2}{*}{$\begin{array}{l}\text { Atatürk Secondary } \\
\text { School }\end{array}$} & TEOG 1 & \multirow{2}{*}{80} & 20 & 100 & 75.3 & 21.16 \\
\hline & TEOG 2 & & 20 & 100 & 84.1 & 19.16 \\
\hline
\end{tabular}

When Table 2 is examined, in TEOG I exam, it is seen that three of five schools (Linyit, Atakent and Atatürk) had a success rate in the range of 65-75 points in the success of the History of Revolution and Kemalism course, while the success rate of the other two schools (Yunus Emre and Çamlıca) was in the range of 50-55 points. It is noteworthy that in the TEOG II exam, the success rate in the History of Revolution and the Kemalism course was higher than TEOG I in all five schools. However, it can be said that the variance in all schools was quite high and close to each other when it is examined the standard deviation values success rates in both the TEOG I and TEOG II the History Revolution and Kemalism course.

\subsection{Findings Related to the First Sub-Problem}

When the relationship between the first written success scores of the 8th-grade students about the History of Revolution and Kemalism course and the TEOG I scores were examined (Table 3), it was seen that there was a statistically significant positive relationship at the level of $r$ $=.77(\mathrm{p}<0.01)$. In other words, in the History of Revolution and Kemalism course, it is possible to say that the results of the written exams of the students organized by the teachers are similar with the TEOG success at around $77 \%$. Another reason for this high relationship may be that the subjects included in the written exam questions of the teachers are the prerequisites for the scope of the TEOG I exam.

Table 3. The relationship between the first written success scores of the fall semester of the History of Revolution and Kemalism course and the success of TEOG I

\begin{tabular}{|c|c|c|}
\hline & Written exam1 (Fall) & TEOG I \\
\hline Written exam 1 (Fall) & & $.769^{*}$ \\
\hline TEOGI & $.769^{*}$ & \\
\hline
\end{tabular}

\subsection{Findings Related to the Second Sub-Problem}

According to the first written exam in fall semester variable, the results of the analysis about the predictions of
TEOG I exam success are given in Table 4. As seen in Table 4, it was determined that the 1st written exam variable in the fall semester predicted the TEOG I exam success statistically ( $\mathrm{R} 2=.59, \mathrm{p}<0.01)$. It is seen that approximately $59 \%$ of the variance in the TEOG I exam success scores of the 8th-grade students were explained by the success scores of 1 st written exam organized by teachers in the Revolution History and Kemalisö Course in the fall semester. This finding may indicate that teachers are careful to prepare written exam questions which are similar to TEOG exam questions.

\subsection{Findings Related to the Third Sub-Problem}

When Table 5 is examined, it is seen that between TEOG I and TEOG II success scores of students have the highest relationship with approximately $\mathrm{r}=.82$. Approximately $\mathrm{r}$ $=.81$ relationship, which is close to this level of relationship, is among the results of the written exam conducted by the teachers in the same period with the success of TEOG II in the spring semester. The relationship between the TEOG I conducted during the fall semester and the results of the written exams conducted by the teachers in the same period are approximately $r=.77$. It is seen that the relationship between the results of the written exam conducted by the teachers in the fall and spring semesters is $r=.73$. In general, due to having a positive relationship at this level between the results of the written exams carried out by the teachers and the results of the TEOG exam, exam content can be interpreted as being frequently consistent with each other.

\subsection{Findings Related to the Fourth Sub-Problem}

When Table 6 is examined, it is seen that the $65 \%$ of the variance in the TEOG II exam the History of Revolution and Kemalism course success scores of the 8th grade students are explained statistically significant $((\mathrm{R} 2=.65, \mathrm{p}$ $<0.01$ ) by the success scores of written exam conducted by the teachers in the same period. This finding may indicate that teachers are careful to prepare second written exam questions similar to TEOG exam questions. 
Table 4. The predicting level of first written exams success scores of the History of Revolution and Kemalism course on TEOG I success

\begin{tabular}{|c|c|c|c|c|c|c|c|c|c|}
\hline Variables & B & Std. Error & B & R & R2 & Adj. R2 & t & p & F \\
\hline Constant & 1.342 & 2.702 & & & & & .497 & .620 & \\
\cline { 1 - 6 } $\begin{array}{c}\text { Written exam 1 } \\
\text { (Fall) }\end{array}$ & .899 & .034 & .769 & .769 & .591 & .590 & 26.192 & .000 & $686.01 *$ \\
\hline
\end{tabular}

Table 5. The relationship between the first written exams success scores of the History of Revolution and Kemalism of the fall and spring semesters and the TEOG I and TEOG II success scores.

\begin{tabular}{|c|c|c|c|c|}
\hline & TEOG 1 & Written exam 1 (Fall) & TEOG 2 & Written exam 1 (Spring) \\
\hline TEOG 1 & & & & \\
\hline Written exam 1 (Fall) & $.769^{*}$ & & & \\
\hline TEOG 2 & $.819^{*}$ & .721 & & \\
\hline Written exam 1 (Spring) & $.729^{*}$ & $.733^{*}$ & $.808^{*}$ & \\
\hline
\end{tabular}

Table 6. The predicting level of TEOG II success scores of the History of Revolution and Kemalism course first written exam success scores in the spring semester

\begin{tabular}{|c|c|c|c|c|c|c|c|c|c|}
\hline Variables & B & Std. Error & $\beta$ & $\mathrm{R}$ & $\mathrm{R}^{2}$ & Adj. $R^{2}$ & $\mathrm{t}$ & $\mathrm{p}$ & $\mathrm{F}$ \\
\hline Constant & 6.290 & 2.525 & \multirow[b]{2}{*}{.808} & \multirow[b]{2}{*}{.808} & \multirow[b]{2}{*}{.653} & \multirow[b]{2}{*}{.652} & 2.491 & .013 & \multirow[b]{2}{*}{$893.41^{*}$} \\
\hline $\begin{array}{l}\text { Written exam } 1 \\
\text { (Spring) }\end{array}$ & .880 & .029 & & & & & 29.890 & .000 & \\
\hline
\end{tabular}

Table 7. The predicting level of TEOG I success scores together with the History of Revolution and Kemalism first written exam success scores in the spring semester in TEOG II success scores

\begin{tabular}{|c|c|c|c|c|c|c|c|c|c|}
\hline Variables & B & Std. Error & $\beta$ & $\mathrm{R}$ & $\mathrm{R}^{2}$ & Adj. $R^{2}$ & $\mathrm{t}$ & $\mathrm{p}$ & $\mathrm{F}$ \\
\hline Constant & 7.460 & 2.080 & & \multirow{3}{*}{.875} & \multirow{3}{*}{.765} & \multirow{3}{*}{.764} & 3.586 & .000 & \multirow{3}{*}{$772,764^{*}$} \\
\hline TEOG 1 & .449 & .030 & .490 & & & & 15,067 & .000 & \\
\hline $\begin{array}{l}\text { Written exam } \\
\text { (spring) }\end{array}$ & .491 & .035 & .451 & & & & 13,857 & .000 & \\
\hline
\end{tabular}

\subsection{Findings Related to the Fifth Sub-Problem}

When Table 7 is examined, when TEOG I and spring semester written exam variables are employed as independent variables, it is seen that $77 \%$ of the variance related to TEOG II $(\mathrm{R} 2=.77, \mathrm{p}=.000)$ is explained. In the model, it is observed that the results of the first written exam and the results of TEOG I are important predictors of the results of the TEOG II exam. When the coefficients are taken into consideration, the relative importance of predicting variables on TEOG II scores are as TEOG I $(\beta=.49)$ and spring semester first written exam $(\beta=.45)$.

\section{Discussion}

In the results obtained within the scope of the study, it was found that the average success of the History of Revolution and Kemalism course in TEOG II exam was higher than TEOG I in all five schools. In addition, when the results were examined, three of five schools had an average success rate of 65-75 points in the TEOG I exam, and the success average of the other two schools was between $50-55$ points. The reason why success average is high in some schools compared to other schools can be explained by the fact that the educational resources of the schools obtained through the study conducted by Önder [13] are significant predictive variables on TEOG scores. Another possible reason may be the individual differences of the students rather than the facilities of the school [18]. When it comes to the details, it can be seen that many variables such as housing income, annual education expenditure for the child, education level of the parents (Aslan, 2017), attitude, motivation, pre-test stress level [9], anxiety [4], selective attention skills [21] number of siblings, having a study room [12] can play a role.

In the research, when it is ranked from high to low according to the relationship levels, it was concluded that there was a statistically significant and positive relationship between the success scores of the first written exam in the spring semester of TEOG I and TEOG II and the History of Revolution and Kemalism course, and the first written exam in the fall semester of TEOG 2 and the History of Revolution and Kemalism course, and fall and spring first written exams of TEOG I and History of Revolution and Kemalism course. Both the content and similarity of the subject and the effect of early learning can be said to have a share in this relationship. The situation of focusing the teaching process which was determined in Çelikel and Karakus's research [3] to the central exam success can be considered among the reasons of these relations.

In line with the research, it was determined that the first written exam of the History of Revolution and Kemalism 
course fall semester explained approximately $59 \%$ of the variance in the TEOG I success scores. Another conclusion reached was that the first written exam in the spring semester of the History of Revolution and Kemalism course announced approximately $65 \%$ of the variance in the TEOG II success scores. In addition, TEOG I and the History of Revolution and Kemalism course spring term first written exam variables were found to explain approximately $77 \%$ of the variance in TEOG II success scores. The fact that the content and application of the TEOG exams in the context of the scoring system, examination place, exam time, exam type, exam method, result notification, question type, number of questions are consistent with the students [15] as well as corresponding with [1] the school curriculum can be seen as an explanatory factor. TEOG exam questions identified in the study of Erol [5] should be consistent with the activities in the student workbook and the corresponding situation of curriculum and course outcomes can be considered as indicators of these relations which were gained. Similarly, Çelikel and Karakuş [3] found a significant relationship between the success of the TEOG exam and the academic success of the mathematics course. As a matter of fact, Özdemir, Yakar and Yavuz's [14] research results are similar to the written exam scores and the written exam scores strongly predict each other in regression analysis also supports the result which was reached. In this context, it can be said that the findings of the study go along with the literature.

\section{REFERENCES}

[1] Akman, O. (2017). Temel eğitimden ortaöğretime geçiş sınavlarına ilişkin 9. Sinıf öğrencilerinin görüşleri (Yayınlanmamış yüksek lisans tezi). Bartın Üniversitesi Eğitim Bilimleri Enstitüsü, Bartın.

[2] Aykaç, N. ve Atar, E. (2014). Geçmişten günümüze ilkögretimden ortaögretime geçiş sisteminin değerlendirilmesi. Cumhuriyet'in Kuruluşundan Günümüze Eğitimde Kademeler Arası Geçiş ve Yeni Modeller Uluslararası Kongresi, 16 - 18 Ocak / January 2014 Antalya, 83-105.

[3] Çelikel, F. ve Karakuş, M. (2017). TEOG sınavının matematik dersindeki akademik başarıyla ilişkisinin ve matematik dersi öğretim süreci üzerindeki etkilerinin incelenmesi. NEF-EFMED, 11(2), 5-18.

[4] Dulkadir, K. (2017). Sekizinci sını öğrencilerinin matematik sınavı kaygısı (Yayınlanmamış yüksek lisans tezi). İnönü Üniversitesi Eğitim Bilimleri Enstitüsü, Malatya.

[5] Erol, H. (2016). TEOG sınavında "T.C. İnkılâp Tarihi ve Atatürkçülük Dersi" ile ilgili sorulan sorular hakkında sosyal bilgiler öğretmenlerinin görüşleri. Elektronik Sosyal Bilimler Dergisi, 15(57), 548-567.

[6] Fraenkel, Jack R. And Norman E. Wallen. (2009). How to Design and Evaluate Research in Education. New York. McGraw-Hill Companies.
[7] Hesapçığlu, M. (1998). Öğretim ilke ve yöntemleri. İstanbul: Beta Yayın ve Dağıtım.

[8] Karasar, N. (2005). Bilimsel araştırma yöntemi. Ankara: Nobel Yayın Dağıtım.

[9] Kesici, A. ve Aș1lığlu, B. (2017). Ortaokul öğrencilerinin matematiğe yönelik duyuşsal özellikleri ile temel eğitimden ortaöğretime geçiş (TEOG) sınavları öncesi yaşadıkları stresin matematik başarısına etkisi. KEFAD, 18(3), 394-414.

[10] MEB (2010) Teftiş Kurulu Başkanlığı. Ortaöğretime geçiş sisteminde SBS ve yeni bir model. http://rdb.meb.gov.tr

[11] MEB (2018) Milli Eğitim Bakanlığ1 Oratöğretime Geçiş Yönergesi. https://www.meb.gov.tr/meb_iys_dosyalar/2018 03/26191912 yonerge.pdf

[12] Okutan, S. ve Daşdemir, İ. (2018). Analysis of science achievements of middle school students in TEOG Exam in terms of some variables. Inönü University Journal of the Faculty of Education, 19(1), 66-81.

[13] Önder, E. (2016). Okulların eğitsel kaynakları ve TEOG puanlar1. Elektronik Sosyal Bilimler Dergisi, 15(58), 837-848.

[14] Özdemir, A., Yakar, L. ve Yavuz, S. (2017). Matematik dersi dönem sonu puanını olușturan bileșenlerin incelenmesi: Performans görevlerinin kaldırılması. Uşak Üniversitesi Eğitim Araştırmaları Dergisi, 3(1), 75-91.

[15] Özkan, E. ve Karataş, İ. H. (2016). Ortaöğretime geçiş sisteminde yapılan değişikliklere ilişkin öğrenci görüşlerinin analizi. Ĕ̈itim ve Ö̆gretim Araştırmaları Dergisi, 5(1), 225-234.

[16] Saraçoğlu, A. S. , Yakar, A. ve Altay, B. (2014). Türkiye'de ortaokula geçiş sürecinde yaşanan sorunlar ve özel dershaneler: Öğrenci-öğretmen-veli görüșleri (Muğla ve Aydın örnekleri). Cumhuriyet'in Kuruluşundan Günümüze Eğitimde Kademeler Arası Geçiş ve Yeni Modeller Uluslararası Kongresi, 16 - 18 Ocak / January 2014 Antalya, 345-387.

[17] Yavuz, M. ve Derinbay, D. (2014). Türkiye'de ortaöğretime geçiş için bir model önerisi. Cumhuriyet'in Kuruluşundan Günümüze Eğitimde Kademeler Arası Geçiş ve Yeni Modeller Uluslararası Kongresi, 16 - 18 Ocak / January 2014 Antalya, 181-201.

[18] Yavuz, S., Odabaş, M. ve Özdemir, A. (2016). Öğrencilerin sosyoekonomik düzeylerinin TEOG matematik başarısına etkisi. Ĕgitimde ve Psikolojide Ölçme ve Değerlendirme Dergisi, 7(1), 85-95.

[19] Yıldırım, A. ve Ekinci, Ö. (2014). Temel eğitimden ortaöğretime geçiş sistemine ilişkin paydaş görüşleri ve öneriler. Cumhuriyet'in Kuruluşundan Günümüze Eğitimde Kademeler Arası Geçiş ve Yeni Modeller Uluslararası Kongresi, 16 - 18 Ocak / January 2014 Antalya, 317-345.

[20] Yeşilyurt, E. (2012). Yapilandirmaci öğrenme konusunda öğretmen adaylarinin yeterliği ölçeği: geçerlik ve güvenirlik çalișmasi. Uluslararasi avrasya Sosyal Bilimler Dergisi, 3(7), 29-45.

[21] Yüksel, M. Y., Sevim, E. ve Çelimli, Ç. (2018). Examination of the relationship between test anxiety and selective attention among adolescents. Elementary Education Online, $17(2), 864-873$ 